\title{
The Coalition of Essential Schools and Rural Educational Reform
}

\author{
Jim La Prad \\ Western Illinois University
}

The Coalition of Essential Schools (CES) has existed for thirty years and includes hundreds of public schools that are diverse in size, population, and programmatic emphasis. A qualitative grounded theory approach is utilized to describe how three rural (non-urban/suburban) high schools operationalize CES Common Principles. This research documents that the CES reform network may be both a viable and underutilized reform model for rural school districts to assist them in achieving educational excellence. Empirical data came from school site visits, interviews and school documents. Grounded theory identifies four working hypothesis that explain how these schools, as CES members, aim to be true to the Coalition's principles. The working hypotheses are: (1) Educational justice, democracy, and citizenship, (2) The educational value of interpersonal relationships between teachers and students, (3) Pedagogical and curricular organization to enhance student engagement and learning, and (4) Pathways to adulthood via the world.

\section{Key words: rural educational reform, coalition of essential schools, grounded theory}

Education has always been evolving; however, the phrase school reform is a relatively new term that began in the late $19^{\text {th }}$ century and continued through the $20^{\text {th }}$ century. Combine this term with a $21^{\text {st }}$ century term sustainable and we ask what does sustainable school reform look like? This is not merely an academic question, but also a question important to educational leaders, researches, policy makers, as well as school board members and perhaps most importantly tax paying citizens. "These are the dog days of public education and large-scale reform" (p. ix). So begins the preface to Hargreaves and Shirley (2012) The Global Fourth Way: the Quest for Educational Excellence. I begin this article with a smaller assertion; the schools we have today require more intentional improvement. We may not need to look globally for improvement ideas as suggested by Hargreaves and Shirley. Over the last hundred or so years many school reform life cycles have met their end; however, the Coalition of Essential Schools (CES) is now in its thirtieth year. Is thirty years long enough to award the term sustainable? As a citizen educator situated in the rural heartland of the Midwest, a study of rural nonurban/suburban CES schools provides valuable insight into the possibility of revisiting this thirty year-old educational reform model.

The Coalition of Essential Schools includes hundreds of public schools that are diverse in size, population, and programmatic emphasis. This article seeks to answer one question; what might this reform model look like in a rural school? Heeding Coladarci's (2007) advice, this article makes no attempt to generalize rural educational context or critique current reform movements in rural schools. Rather, the aim is to share possibilities for reform. A grounded theory approach is utilized to investigate and describe the impact of the Coalition of Essential Schools reform model on these schools.

\section{Background: Rural Educational Reform?}

Unlike many reform efforts in urban or suburban school districts, rural educational reform has taken different routes. Rural communities and school districts view films like Waiting for Superman (2010) or The Lottery (2010) and are sympathetic to the plight of urban schools, bewildered parents, and underserved children. However, the contextual situation of their rural communities is very different. Often rural school districts are the largest employer in the area and along with the waves of federal and state educational mandates, are faced with consolidation issues that place educational reform agendas on the distant 'back burners,' however; close to one-fourth of all United States students attend a rural school and the quality of their education matters (Johnson, Showalter, Klein, \& Lester, 2014). While, Budge (2006) and Sherwood (2000) explain that it is difficult to define the exact characteristics that identify rural schools and their communities it is recognized that they are very diverse and unique. Historically, Tyack (1972) acknowledged that this uniqueness has created some tension at state and national levels and was identified as the "Rural School Problem" (p. 5). Kannapel and DeYoung (1999) claim, "Over the past 100 years, the drive to make rural schools more centralized, standardized, bureaucratized, and professionalized has nearly robbed them of their distinctiveness and has failed to deliver on the promise of improved quality of education" (p. 76). However, Kannapel (2000) was 
cautiously hopeful that some middle ground could be found between standards-based reform and rural school improvement efforts. Where is the middle ground? What I have witnessed is regional educational leaders struggling to meet AYP under the standards based accountability movements and complaining that state legislators are driving education into the ground. Schafft (2010) and Powell, Higgins, Aran and Freed (2009) explain that the current standardized accountability movement has had devastating effects on rural schools by weakening educational programs, disempowering educational leaders, demoralizing teachers, and disengaging students. Sadly, many of the rural students along with their urban and suburban counterparts attend schools that struggle to provide the educational experiences that develop the knowledge and skills necessary for the engaged citizenship our twenty-first century democracy demands (Brown, 2014; Trilling \& Fadel, 2009; Wagner, 2008).

\section{Educational Reform and the Coalition of Essential Schools}

Educational reform is hardly new to American education. Often educational historians position the reform of the American high school beginning with the 1893 Committee of Ten and the standardization of high school curriculum that later organized in Carnegie units (Tyack \& Cuban, 1995). However as Tyack and Cuban suggest, we have merely been tinkering with schools and school programs. More than forty years ago, in a time when test makers and textbook companies were not driving educational reform, Theodore (Ted) Sizer, a reform minded educational historian, gathered his thoughts and speculations regarding the possibility of educational reform. Sizer (1973) states: "Fundamental changes are needed in American formal education, yet the resistance to those changes is neither mindless nor conspiratorial. There are reasons why things are as they are. These must be explored dispassionately" ( $\mathrm{p}$. vii). With this in mind, one can hardly argue that the ideas laid out by the 1893 Committee of Ten still remain with our retention of the Carnegie units of study. However, Sizer focuses his exploration suggesting ways to approach educational reform that potentially has sustaining impact.

Sizer (1973) sketches out three aims of education toward which every person should strive. First, power is identified as "the maximum use of [their] intellectual and physical faculties for personal and corporate ends. [They] should be able to understand, to select, and to act in a purposeful, deliberate manner" (p. 39). Second, agency is identified as "the personal style, assurance, and selfcontrol that allow [them] to act in both socially acceptable and personably meaningful ways" (p. 39). Third, joy is identified as "the fruit of aesthetic discipline, of faith, and of commitment. The human animal laughs, and wonders, and ... is capable of love" (p. 40). He continues explaining that our democratic society must be bound to facilitate and enhance these ends. Further, Sizer focuses on these "ends in view" (Dewey, 1916) as he begins his own study of American high schools in the late 1970s. Sizer (1983) explained this study focused primarily on the "inside of schools ... [the] critical triangle of student, teacher, and subject and on the climate of the school in which this triangle functions" (p. 33). He would report that sadly this critical triangle has remained unchanged in 100 years. Explaining, "The American high school may be this century's most farreaching and generous social invention.

Unfortunately, and despite well-intentioned, sincere efforts, many schools are not uniformly productive and serve some of their students poorly" (p. 34). As a whole, Sizer found American high schools failing to meet the ends he identified in 1973. The first full report from this study was published in 1984 as Horace's Compromise.

Sizer's study and writing project would span more than fifteen years and produce an educational trilogy Horace's Compromise (1984), Horace's School (1992), and Horace's Hope (1996) featuring Horace Smith, a fictitious high school teacher and educational reformer. Horace Smith is the archetypal Freirean teacher who views the teacher-student relationship to be dialogical (Freire, 1970; Freire, 1998). He is at the same time foundationally Deweyian in noting that this relationship cannot flourish within the confines of a 19th century-style, scientifically-managed bureaucracy that public schooling had become and remains today (Dewey, 1897; Dewey, 1916). The publishing of Horace's Compromise also coincided with a thirty-year national school reform effort led by Sizer and the Coalition of Essential Schools that began with ten schools in 1984.

Toch (2010) explains that Sizer believed that smaller schools with reorganized teaching loads would foster stronger bonds between teachers and students that "engendered genuine caring and mutual obligation" and a curriculum "that taught fewer topics more deeply" foster the conditions to improve learning (p. 74). Anderson and Shirley (1995) assert that strong school leadership and the "endorsement of, commitment to, and proper implementation of nine principles" are imperative to the educational reform model's success (p. 406). Over the past thirty years the Coalition's principles have evolved and 
been modified to meet the Coalition's ideals to include the addition of a tenth principle. Today this reform movement has reached almost every state, more than a thousand schools and remains a national leader in public education transformation and reform by striving to create and sustain a network of personalized, equitable, and intellectually challenging schools guided by principles:

- Learning to use one's mind well.

- Less is more, depth over coverage.

- Goals apply to all students.

- Personalization.

- Student-as-worker, teacher-as-coach.

- Demonstration of mastery.

- A tone of decency and trust.

- Commitment to the entire school.

- Resources dedicated to teaching and learning.

- Democracy and equity. (Coalition of Essential Schools, 2012).

The educational ends Sizer (1973) identified as power, agency, and joy are interwoven within today's CES principles. Wagner (2008) highlights two CES public schools, The Met in Rhode Island and the Francis W. Parker Charter Essential School in Massachusetts, in his chapter on schools that work (pp. 229-253). Nationally, both these schools and most CES schools are open learning laboratories to facilitate educational reform where visitors are welcome.

\section{Grounded Theory Methodology}

Drawing upon the historical and philosophical framework of CES as an educational reform model, this study investigated three CES high schools. This inquiry sought to uncover what these schools and this reform model does that makes it a viable model for other rural schools and rural communities. I desired to uncover a phenomena that is based in the context of these schools and Coalition of Essential Schools itself. Grounded theory is the qualitative methodology used for this inquiry.

\section{Constructively Grounded}

This qualitative inquiry is constructively grounded in a manner explained by Strauss and Corbin (1990) to be:

one that is inductively derived from the study of a phenomenon it represents. That is, it is discovered, developed, and provisionary verified through systematic data collection and analysis of data pertaining to that phenomenon. Therefore, data collection, analysis, and theory stand in reciprocal relationship with each other. One does not begin with a theory, then prove it. Rather, one begins with an area of study and what is relevant to that area is allowed to emerge (p. 23).

Strauss and Corbin further explain that this process is beneficial because it allows the researcher and their analytic story to be "faithful to everyday reality" that is generated from the data. The story is then understandable and makes sense to persons, who were involved in the inquiry, practitioners in a given field, and potentially those on the periphery of schools (e.g. parents, citizens, and policy makers). Comprehensive conceptual data and interpretations can produce a theory which is "abstract enough and includes sufficient variation" to make it applicable to contextual situations that are both practically and theoretically related to the nature of schooling. The theory that emerges from this inquiry is grounded in both the data and my interpretations and analysis of this data, which are theoretically sensitized (p. 23).

Cautiously, with a constructive approach to grounded theory, I intend to find a middle ground between positivism and relativism and describe what is found using this approach as Charmaz (2000) writes "as flexible, heuristic strategies rather than formulaic procedures" (p. 510). Consistent with my constructivist assumptions and grounded theory methodology, I draw on abductive reasoning as a data analysis strategy. Atkison, Coffey, and Delmont (2003) distinguish abduction as an analytical process that lies between inductive reasoning and deductive logic. Derived from Charles Sanders Peirce, this type of reasoning best defines this work as the researcher is engaged "in 'drawing out' possible abstractions from observed cases, and using those to formulate working hypotheses that can in turn be tested against new cases and observations" (p. 149). The working hypotheses that I formulate are the means to achieve the ends these schools aspire to reach; these ends are articulated in the CES Common Principles. Selection and analysis of the qualitative data follow the methods outlined in Charmaz (2008), Patton (2002), Charmaz (2000), Denzin and Lincoln (2000), Seidman (1998), and Lincoln and Guba (1985).

\section{Data}

A purposive sample of three high schools provided the data for this grounded study. Each school is contextually bound by their geographic, socioeconomic, and community demographics with a unique common element - all three schools are members of the Coalition of Essential Schools and are guided by CES Common Principles. Site visits produced ethnographic memos; interviews with 
principals and teachers were recorded and transcribed; and school websites, school curriculum outlines and guides, school historic records and handbooks, journal and newspaper articles involving schools, conference presentations and proceedings by schools, and state educational department websites comprised documents for analysis. Each site visit lasted a minimum three days and included classroom and advisory visitations, student lead tours, and attendance at exhibitions of learning. Semi-structured interviews ranging approximately $30-60$ minutes in length were conducted with school leaders and teachers offered vantage points regarding the impact of the reform model on their school. In total four leaders ( 3 principals, 1 assistant principal) and fourteen teachers were interviewed.

Schools. The three schools selected for this study identify themselves as Coalition Schools. All three are non-urban and non-suburban by demographic indicators. As Coladarci (2007) explains, "There is no single definition of rural, as any reader of rural education research quickly, and often incredulously, learns" (p. 2). This author acknowledges the difficulty of isolating a definitive definition for what is or is not a rural school. However, the demographic and contextual information of two of the schools selected for this study warrant the identification acknowledgment as rural schools. Two are identified as being located in rural school districts and the other in a town district (National Center for Education Statistics, 2013). The school located in the town district is included in this study due to school's size, as it is a small high school with 140 students. Two schools are located in the Midwest and one is located in the Northeast. Pseudonyms are used for the schools and school personnel for confidentiality and anonymity as per IRB protocol. What follows are important contextual factors regarding the schools to include length of CES affiliation, school size and student demographics, leadership structure and staff allocations.

Jane Adams High School (JAHS). JAHS is a rural school located in the Northeast that has been an official member of CES since 2001. However, CES principles have guided many of its reforms since 1992. While rural in location, JAHS is 20 miles from a public university in a neighboring town. During the 2011-12 academic year, 1005 students attended JAHS; ethnic/racial backgrounds were $1.6 \%$ Asian, 1.6\% Black, 1.2\% Hispanic/Latino, and $95.6 \%$ White-non-Hispanic. School report card data report that $41.5 \%$ of JAHS students are considered economically disadvantaged. The leadership of JAHS includes a principal, an assistant principal who serves also as an academy dean, and two additional academy deans. The school evenly divides the freshman class into three academies; students remain in these vertical academies for all four years. There are eighty teachers at JAHS, 55\% hold master degrees. JAHS uses a four period block schedule with 8 courses taught during an academic year (Jane Adams High School, 2012a; 2012b; and 2012c).

John Dewey High School (JDHS). JDHS is a rural school located in the Midwest and has been an official member of CES since 2003, however CES principles have guided many of its reforms since 1993. While rural in location, JDHS is 15 miles from a public university in a neighboring town. During the 2011-12 academic year, 321 students attended JDHS; ethnic/racial backgrounds were 3.5\% Black, $1.0 \%$ Hispanic/Latino, 3.5\% Multi-racial, and 92\% Whitenon-Hispanic. School report card data report that $51.6 \%$ of JDHS students are considered economically disadvantaged. The leadership of JDHS includes a principal who also serves as the district's superintendent and an assistant principal. There are twenty-four teachers at JDHS, 67\% hold master degrees. JDHS uses a four period block schedule with 8 courses are taught during an academic year (John Dewey High School, 2012a; 2012b).

Maxine Greene High School (MGHS). MGHS is one of three small high schools located in a town of 50,000 or less residences and is more than 35 miles from an urban area in the Midwest. MGHS has been an official member of CES since 2010. During the 2011-12 academic year, 140 students attended MGHS; ethnic/racial backgrounds are $6.5 \%$ Asian, 9.7\% Black, $12.9 \%$ Hispanic/Latino, and $71.0 \%$ White-non-Hispanic. School report card data report that $48.4 \%$ of MGHS students are considered economically disadvantaged. The leadership of MGHS includes a director who oversees the elementary, middle and high schools and dean of culture who leads the high school. There are ten teachers at MGHS, $60 \%$ hold master degrees. MGHS is on trimesters and embraces project-based learning utilizing modified block scheduling with two core academic classes in the mornings on an $\mathrm{A} / \mathrm{B}, \mathrm{C} / \mathrm{D}$ alternating day rotation and three, one hour long, project and seminar blocks in the afternoon (Maxine Green High School, 2012a; 2012b; and 2012c).

\section{Method of Analysis}

Theoretically, Lincoln and Guba (1985) and Atkison, Coffey, and Delmont (2003) develop the use of working hypotheses in qualitative inquires. A "working hypothesis" while tentative for both the 
current situation and future situations, is both useful and valuable in understanding a phenomena being studied. Analytically, I refer to Charmaz (2008) to explain that the working hypotheses developed here "emerge from wrestling with data, making comparisons, developing categories, engaging in theoretical sampling and integrating an analysis" ( $p$. 207). This analysis essentially followed the Chicago tradition with five modified steps. First, the research established "intimate familiarity with the settings(s) and the events occurring within it" (p. 222). Prior to site visits I studied school websites and became familiar with each school's geographical demographics and boundaries. Simultaneously, Sizer (1984), Sizer (1992), Sizer (1996), Meier (1995), Wood (2005), and CES (2012) were reviewed for Coalition Essential School background. Second, I focused on "meanings and processes" (Charmaz, 2008, p. 223). Reviewing curricula guides with the philosophical understanding of CES conceptual framework generated questions for interviews. School visits and document analysis were then compared with research participant's responses and statements. Questions, assumptions and understandings began to emerge. Third, I engaged "in a close study of action" (p. 224). This was achieved by continually asking the questions; what were these schools doing differently and why? What is different about these schools' culture and climate? How are these schools being true to the CES principles, and what are some possible working hypotheses? Fourth, was to "discover and detail the social context within in which action occurs" (p. 225). Here is where I found examples from within the schools that identify the existence of the phenomena and then located examples of similar phenomena in different locations fitting lines of action together to frame out a possible working hypothesis. The fifth and final step was to pay "attention to language" (p. 226). "Language shapes meaning and influences action. In turn, actions and experiences shape meanings" (p. 226). Does the rhetoric match the reality; are the ends these CES schools aspire to really being met? In summary these steps lead to the working hypotheses that outline and frame the findings of this article.

\section{Positionality}

From an ethical standpoint, especially conducting a qualitative inquiry using grounded theoretical methods; I must acknowledge my own positionality. As a qualitative researcher, I realize I am the "primary instrument" for data collection and analysis. Who I am, my own experiences, background, and persona effect the construction of this inquiry. I myself grew up and was schooled in urban, rural, and suburban educational environments as my family moved around the Midwest due to my father's employment in the chemical manufacturing industry. My Midwestern initial rural experience came when my family lived in the small town of Grand Rapids, Wisconsin for three years in the mid 1970s. While, I would consider this a rural living experience I attended grades 4-6 at an elementary school in the larger town of Wisconsin Rapids, Wisconsin; regardless both were vastly different than Detroit, Michigan where my family lived prior. My remaining education would be in what I would consider suburban/urban environments in the metropolitan areas of Detroit and Chicago. Following college and military service I taught high school and middle school science and mathematics in Virginia in both suburban/urban and rural environments. I was first introduced to Sizer's Horace's Compromise in the early 1990s while in my first graduate education course and it left a lasting impression. A memorable portion of my P-12 teaching experience occurred in rural Virginia in the early 2000s prior to current position in the education college of a regional comprehensive university in the rural Midwest. As an educational philosopher for more than ten years, I have worked with and taught a majority of preservice and in-service teachers as well as educational leaders who work in the regional rural districts surrounding my university. I am empathetic to their situations, as many of these educators have shared their struggles with me regarding the paralyzing nature of the current standardized accountability movement. Part of my motivation with this research is to share insights on a school reform model that I have been familiar with for more than twenty years.

\section{Working hypotheses}

I recognize that my positionality influenced my data collection, analysis, and abductive reasoning as I developed working hypotheses to help explain how these three schools, as Coalition of Essential School members, aim to be true to their CES Common Principals and facilitate learning environments vastly different from any of the environments I have experienced as student or teacher. These working hypotheses are contextually bound to help tell the stories about these schools as well as help organize this report. They are: (1) Educational justice, democracy, and citizenship, (2) The educational value of interpersonal relationships between teachers and students, (3) Pedagogical and curricular organization to enhance student engagement and learning, and (4) Pathways to adulthood via the world. 
When Darling-Hammond (2010) stated at the end of The Flat World and Education: "Now more than ever, high-quality education for all is a public good that is essential for the good of the public" ( $p$. 328). The goods she is referring to are ethical goods, the same goods that are evident within my study. When constructing cases and conducting cross-case analysis, the above theme often conjured the wellworn statement by John Dewey: "What the best and wisest parent wants for his [or her] own child, that must the community want for all of its children. Any other ideal for our schools is narrow and unlovely; acted upon, it destroys our democracy" (Dewey, 1899, p. 34). As Noddings (1992) explained, Dewey was not advocating the same, equally, one-size fits all education for all children but "an education that matched his or her needs, capacities, and interests" (p. 44). This is the type of educational justice that CES schools advocate and through their curriculum programing, strengthens students democratic and citizenship skills. The working hypothesis for this section educational justice, democracy, and citizenship is centered in four of the CES common principles: Learning to use one's mind well, Goals apply to all students, A tone of decency and trust, and Democracy and equity. What follows is evidence from the schools.

\section{Discussion and Findings}

John Dewey High School (JDHS) is an untracked high school and approaches educational justice by requiring that all students complete, submit, and defend a graduation portfolio. The overview of the graduation portfolio states:

There are two goals for the Graduation Portfolio. The first is to enable the faculty of JDHS to review each graduate's readiness to enter the world after high school. The second, and perhaps more important goal, is to enable each student to reflect on his or her education and how prepared he or she is for the responsibilities of democratic citizenship, and the world of work, and a life of learning (John Dewey High School, 2012a, p. 17).

There are three sections to this graduation portfolio: career readiness, democratic citizenship, and skills for lifelong learning. The student's career readiness section must include a resume, high school transcript, evidence of researching career options, descriptions of college visits with artifacts, acceptance letters (college, military, or employment), scholarships or financial awards, ACT/ASVAB/SAT results, reference letters (minimum of two), and a reflective statement (one-two pages). Completing the democratic citizenship section provides the student "the opportunity to demonstrate your readiness to take on the greatest responsibility in our culture, that of citizen" (John Dewey High School, 2012a, p. 19). This portfolio section involves a point system that includes three categories for active citizenship in the school, taking a stand, and active citizenship in the greater community. The skills for lifelong learning section require students to include course work artifacts that demonstrate their competence as a learner along with a written defense as to how this artifact demonstrates mastery of skill in that area. Four areas that must be included are writing, math, social studies, and science. Students must also include one or more of the following areas: the arts, technology, agricultural sciences, foreign language, physical fitness, consumer science or other elective area. They must also include an annotated bibliography of at least three books they have read beyond ones required for their courses. Students must orally defend their portfolio with a required ten to fifteen minute presentation followed by a question and answer period.

While, Jane Adams High School (JAHS) also has a graduation portfolio requirement similar to JDHS that includes four elements spread over four years: the Freshman Round Table, the Sophomore Gateway, the Junior Portfolio and the Senior Exhibition. Their approach toward educational justice is nuanced in other ways as well. First, JAHS guidance office intentionally places students heterogeneously into their freshman year academies, equitably distributing students from the three distinct communities that comprise their school district. This heterogonous mixing requires each freshman academy to develop their own ethos and sense of community, which not only diminishes disciplinary issues at JAHS but also better prepares graduates for our pluralistic democracy. Second, JAHS is an untracked high school and its graduation requirements include a common curriculum beyond many high schools nationwide. One teacher explains: With our curriculum we have to tell kids that they are capable of doing complex things. They are capable of achieving at high levels. They are capable of very rigorous stuff. But before they will believe that, we must ask it of them. So when I think about the common core, it is saying all kids deserve physics, all kids deserve five good mathematical experiences that are going to push them ... We are assuming that all kids can perform at high levels (K. Knight, personal communication).

What is noteworthy about this curriculum is that four science credits are required for graduation to include physics. Each of the high schools three academies has a physics teacher and physics laboratory classroom 
with ample laboratory equipment to conduct engaging investigations ranging for propulsion and rocketry to electricity and wind turbines. This curriculum is for ALL JAHS students not a select few college bound students.

Maxine Greene High School (MGHS) is also an untracked high school that demands high expectations for all their students. While they approach educational justice similarly a few programs are noteworthy. Daily twenty-minute advisory periods include an inquiry class where students learn how to form and make arguments by "exploring a number of current issues - both divisive and crucial - students will develop the skills necessary to convey their own thoughts while, at the same time, understanding other points of view and working toward a common end point" (Maxine Green High School, 2012c, p. 10). Along with the advisory periods, MGHS has weekly hour long town hall meetings that provide "a place to learn how to connect with others, a place to share opinions, a place for bringing school and the rest of life together, a place to integrate family into school, a place to celebrate, and a way to connect as a community" ( $\mathrm{p}$. 10). Town meetings are a place where students practice their democratic skills of listening, critiquing, compromising and jointly coming to agreement on school wide decisions. In a focus group meeting with teachers from MGHS when asked what they would say or offer to a group of teachers in a traditional school who were looking to change one teacher spoke up "Trust your kids..." the nine other teachers all nodded and agreed. MGHS models democracy with its programing and the attitudes their teachers have towards their students.

While three schools approach educational justice, democracy, and citizenship in slightly different ways, what is important to understand is that these ideals are foundational to how these schools viewed themselves as public schools with public interests. The public interest in leaving no child behind and no citizen unprepared for the democratic life ahead of them is not just rhetoric. The educational practices are practical models for rural educational reform. Keeping in mind that the application of the CES principles of Learning to use one's mind well, Goals apply to all students, A tone of decency and trust, and Democracy and equity guide decisions unique to each school community.

\section{Educational value of interpersonal relationships between teachers and students}

Was Tibbetts in your Period One class? No, Horace tells the assistant principal; that's why I marked him absent on the attendance sheet. The assistant principal overlooks this sarcasm. Well, he says, Tibbetts wasn't marked absent at any other class. Horace replies, that's someone else's problem. He was not in my class. The assistant principal: You're sure? Horace: of course I'm sure (Sizer, 1984, p. 15).

Sadly, similar exchanges as the one between the fictitious Horace Smith and his assistant principal occur daily at American high schools regardless of size or geographic location. All too often attendance is viewed as a legal or compliance issue, even in rural schools where little concern may be felt for Tibbetts, especially if he or she might be that disengaged and troublesome 'farm kid'. Wood (2005) states:

Most American high school students share seven or eight teachers with more than two hundred peers every day they are in school. Such numbers clearly spell out the impersonal nature of the paces in which we expect the most personal act of learning to take place. (p. 57) The CES schools in this study all utilize a form of block scheduling and programing (e.g. advisories) to enhance the interpersonal relationships between teachers and students to counter the dilemma and compromise Horace Smith and his assistant principal experience. It is through the possibility of an interpersonal relationship that Tibbetts no longer remains a number, but a student someone cares about. CES schools embrace the notions of Noddings (1984) and relational aspects of care that include the moral relationship between the "caring one" (the teacher) and the "one cared for" (the student) that embody engrossment and emotional displacement (pp. 24, 30). This working hypothesis is centered on three of CES common principles: Personalization, Student-as-worker, teacher-as-coach, and A tone of decency and trust. What follows is evidence found in the schools.

Jane Adams High School (JAHS) embraces the value of interpersonal relationships quite differently from most traditional high schools programmatically utilizing three teamed vertical academies. Each freshman team has five teachers that work solely with 75-80 students. These five teachers have a daily eighty-minute common planning period. Teachers at a minimum will dedicate one period a week discussing student issues and student progress. These teamed academies become like home for both students and teachers alike. One JAHS teacher explained: "This is their home ... our kids trust us with everything ... [we talk to them] like they are young adults .... it's this mutual respect with the kids." One dean shared that when JAHS hires teachers from other schools, these teachers are amazed at the culture they find at JAHS and he 
attributes that to the teamed vertical academies. He explained that it is the way the school is structured: Teaming, small groups, common teachers, with teachers, [students] feel that they really know them and care about them ... I think that shapes our culture that is what just permeates our whole school. In terms of learning that creates an environment, that creates a culture of care, because we have kids that come from all different walks of life. (A. Mink, personal communication)

As summer break approached the teachers acknowledged that the end of the school year creates a different tension as students are realizing that the ending school year requires that they leave their home, perhaps the greatest source of continuity for some students.

At John Dewey High School (JDHS) advisories are broken down into intentional groupings of freshman / sophomores and juniors / seniors. Students will typically spend two years with the same advisor. Advisory groups range from six to eight students in each grade for a maxim total of sixteen students per advisory. The JDHS Handbook states that advisors will help: "with your schedule, tracking your discipline, be the person you should go to if you need help or assistance, and can steer you to a wide range of school resources" (John Dewey High School, 2012a, p. 17). At JDHS, continuity and modeling are important and after twenty years of tweaking their advisory program they feel that the 2011-2012 version is the best so far. During freshman and sophomore advisory, they are able to focus on transitioning into high school and assisting students in negotiating the academic, social and community expectations school brings. Junior and senior advisories are able then to concentrate on preparing students for their transition out of high school onto college or the workforce as they fulfill the graduation requirements including Senior Project and their graduation portfolio. When discussing advisories, one JDHS teacher claims that their students are comfortable talking to adults because "they do have a lot more adult conversations." Another teacher explains, "Every Monday morning we do sit down with our advisories and just talk, and the kids feel comfortable talking to their teachers, they don't feel threatened, they feel like they are treated fairly, equally." Following-up what this teacher said another teacher responds: "I would say in a traditional high school, you do get that, but that is usually with your honors classes, AP classes only." Building trusting and personalized relationships are important at JDHS. It's a belief system and Bill Steel, JDHS Principal, explains:
I believe the way to have young people become consciously engaged adults is to put them around consciously engaged adults. You learn to be a grown-up by watching grown-ups. So, if the only grown-ups you see are harried and can't get to you and don't have time for you and are rushed and are disorientated that's where you get your education and Ferris Bueller is right. "Let's go on vacation every day because they will not notice we are gone" ... [Along with] advisory, I try to drive class size as low as I can. Like my one teacher said, "I have sixty kids a day and I know them real well." He knows their work habits. He knows everything about them. (B. Steel, personal communication) Maxine Greene High School (MGHS) believes that their "teachers are teachers of students as well as teachers of disciplines" (Maxine Green High School, 2012c, p. 9). This distinction and attitude builds mutual respectful relationship between students and teachers. Students are assigned to an advisory group when they enter MGHS and remain with that advisor until graduation. "Advisories play an integral role in our dedication to continuously building a sense of culture and community" (p. 9). Advisory meets at least twenty minutes every day and this ensures that each student has a positive relationship with at least one adult who personally knows them and the other students in their advisory. MGHS Program of Study explains:

The advisor-advisee relationship begins with a personal Entrance Conference for each student with his or her advisor to complete the class registration process. At this conference the advisor learns more about the student and offers guidance in course selection to meet the student's long- and short-term goals. (Maxine Green High School, 2012c, p. 9)

Students meet regularly one-on-one with their advisor throughout the school year to identify personal strengths and growth opportunities. One teacher shared this about the relationships that form. I think it is huge, for the kids to get to know each other and for them to get to know you, that you are a human being. That you have a family, you have a past, [and] there are things that you do outside school that you love. They see us at a different level and that helps them connect. (K. Jones, personal communication)

MGHS advisories are a made up of sixteen students, four from each grade level and one teacher who spends their time talking, checking in and coaching students on their progress both academic and social. During advisory students may be working on projects in groups or individually maintaining their learning and progress portfolios. 
What is important to note is that rural schools are often small schools to begin with. What is critical to understand is the intentionality that these CES schools approached building personal relationships between their students and teachers. These personal relationships are intended to not merely improve the social relationships in the school and classroom to diminish discipline problems; their aim is three fold. First, it is know their students well to assist in guiding and facilitating learning. Second, to model appropriate and mutually beneficial relationships for emerging young adults to better interact in the world. Third, teachers often find the relationship they build with their students led to great breadth and depth of satisfaction and joy in teaching. All three of these principles: Personalization, Student-as-worker, teacher-as-coach, and A tone of decency and trust embody the findings generated from this working hypotheses.

\section{Pedagogical and curricular organization to enhance student engagement and learning}

In a certain sense every experience should do something to prepare a person for later experiences of a deeper and more expansive quality. That is the very meaning of growth, continuity, reconstruction of experience (Dewey, 1938, p. 47).

Dewey was very critical of the experiences students had with schooling. His criticisms both cautioned and challenged educators in leading reforms in schooling. Close to eighty years of tinkering with educational reforms stand between Dewey's words and today, sadly most school's core curriculum remains unchanged especially as fortyfive states have signed on to the Common Core in 2013. Noddings (1992) suggests, "We need to give up the notion of an ideal of the educated person and replace it with a multiplicity of models designed to accommodate the multiple capacities and interests of students" (p. 173). CES schools certainly embraced Noddings' suggestion and understood Dewey as they organized their schools for engagement and learning. Obviously, Sizer (1992) understood this and remarked:

A mindful school is clear about what it expects of a student and about how he [or she] can exhibit these qualities, just as a mindful student is one who knows where he [or she] is going, is disposed to get there, and is gathering the resources, the knowledge, and the skills to make the journey. (p. 27)

Mindful CES schools guided by the principles: Less is more, depth over coverage; Goals apply to all; Personalization; Student-as-worker, teacher-as-coach;
Demonstration of mastery; and Resources dedicated to teaching and learning are unique in their design of organizing student experiences that foster engagement and learning. What follows is evidence found in the schools.

When it comes to pedagogy and curriculum, Jane Adams High School (JAHS) organizes their school with heterogeneous groupings,

interdisciplinary teams, block scheduling, and student exhibitions of learning. Kathleen Knight, one of JAHS lead teachers, explains what makes them different from the surrounding regional schools:

The approach we take to classwork. It is a student-centered learning environment. There is not a ton of stand-and-deliver instruction. Now, there is some direct instruction, ten-fifteen minutes, but it is the embodiment of student as worker, teacher as coach. When you walk into a classroom you see the students doing the work. (K. Knight, personal communication) During freshman and sophomore years, student exhibitions of learning are the Roundtable and Gateway to student led conferences that include a panel of parents, a teacher and a peer. In these conferences, students reflect on their year and set goals for the coming year. Kathleen Knight explains, with these types of exhibitions students "take away metacognitive and effective skills. Who am I as a learner, what do I need as a learner, can I set goals, can I change my behavior to meet goals" (Kathleen Knight, personal communication). Junior year students complete the Pathway, "an intensive selfexploration process, helping students to bridge the gap between their knowledge of themselves and where they want to go after high school" (Jane Adams High School, 2012b, p. 3). Senior year students complete their Senior Exhibition, a graduation requirement at JAHS, where a student research project is evaluated with a rubric of essential skills by a panel of three teachers and one underclassman. For this exhibition, students select a research topic, craft a clear research question, and conduct first-hand inquiry on the topic throughout their senior year that demonstrates mastery of a series of characteristics and to exhibit the competency to graduate (Jane Adams High School, 2012b, p. 3). Kathleen Knight expresses what is really impressive about the senior exhibitions is "the whole public presentation of knowledge. We are an academic community, they are not just doing it for their own edification, but others will learn from them [as well]" (K. Knight, personal communication).

John Dewey High School (JDHS) also organizes its curriculum with block scheduling to allow for greater depth in material with extended learning opportunities, rather than the shallow 
coverage of material that occurs in the traditional forty-five to fifty minute class period. One teacher explains:

We have time to do math labs that you would not have that luxury [to do] in a forty-five minute period. You have more time to plan a variety of activities to teach the same concept. Where you are more likely to be able to engage all the students at some point . . . you have more time to access the different types of learning. (S. Nichols, personal communication) Along with block scheduling JDHS requires students to complete a senior project prior to graduation.

Each student at JDHS finishes his or her career with the opportunity to engage in an independent learning experience through doing a Senior Project . . . an independent learning experience where you take on learning a new skill or gaining new knowledge. The actual product of your work should reflect what you have learned. This will be a lot of work, so choose a project in an area that you are passionate about. This is your turn to shine, to guide your own learning, to take control of your own education. (John Dewey High School, 2012a, p. 2)

The projects are time intensive and require students to first construct and defend a proposal before their project advisor and two additional teachers. Once their project is completed, they must again defend what they have learned before the same teachers prior to their public display of learning at Senior Exhibition Day at the end of the academic year. During this public exhibition, one community member remarked: "You know when I graduated from high school I only got a slip of paper, nothing like this," as he points to a restored 1953 John Deer Tractor that his grandson rebuilt for his senior project. Senior Exhibition Day is a public display of the knowledge and skills that students have mastered while in high school. Late in the evening at this public exhibition, Bill Steel JDHS principal made an interesting remark: "You know what I want my kids to learn from these projects? I want these kids to realize that every day for the rest of their life is no different than their senior project, and they've got what it takes."

Maxine Greene High School's (MGHS) approach to pedagogy and curriculum is the most unique when compared to the other two schools. While MGHS also utilizes a modified block schedule, it combines 21 st Century skills and content integration with project-based learning all four years. Students are constantly working on a specific project through their project class. These projects may be individual or collaborative, regardless each project is viewed to solve real-world problems through an "innovative product or idea that is new and of value" (Maxine Green High School, 2012c, p. 4).

21 st Century skills are woven into all aspects of MGHS' curriculum that includes:

Digital and technological literacy, innovative thinking, interactive communication, effective use of real-world tools, personal and social responsibility, prioritizing and managing for results, teaming and collaboration, curiosity, creativity, and risk-taking, cultural literacy, and global awareness. (Maxine Green High School, 2012c, p. 8)

Content integration is enhanced through design, engineering, arts, sciences, and humanities via project-based learning that allows for academic mastery in core subjects across multiple disciplines. Language arts and communication skills are emphasized within the academic disciplines, including assessment in public speaking, writing, and research skills that are utilized in project exhibitions. Pedagogically a teacher explains:

People come with things they are good at, things that they are interested in, things they want to do, and we are kind of pulling the learning out of them instead of doing it to them. Taking their ideas and tapping into what is there to begin with and adding more, and going beyond what they are just interested in ... everything matters. (M. Bushnell, personal communication)

At the end of each semester MGHS students will spend two days presenting their exhibitions of learning to their peers, teachers, teacher-evaluators, and community in open public forums. These exhibitions are twenty-minute performances and students demonstrate what they have learned and mastered through their project. At the end of the day following the final exhibition MGHS' teachers asked their students to gather for a public discussion and question and answer period with the community. One community member asked, "What does it take to get students like yourselves to do these projects?" After a short pause one student replied, "Well, just asking us to do them, most schools don't ask students to do anything like this."

Sizer (1996) explained, "Essential schools have found that if the Exhibitions require and active defense and demonstration of the use of knowledge, then the practice for such work has to include appropriately active engagement" (p. 89). This makes sense to CES schools as they tie curriculum standards and pedagogy together. Knowing if we want our students to be active and engaged citizens they must practice and have access to educational models while in school of active and engaged learning. In this way 
the common principles: Less is more, depth over coverage; Goals apply to all; Personalization; Student-as-worker, teacher-as-coach; Demonstration of mastery; and Resources dedicated to teaching and learning are not left to chance. All students graduate with a personalized depth of knowledge and skill that is transferable to life outside of school.

\section{Pathways to adulthood via the world}

We never educate directly, but indirectly by means of the environment. Whether we permit chance environments to do the work, or whether we design environments for the purpose make a great difference (Dewey, 1916, p.19).

CES schools heed Dewey's words and are intentional in shaping the educational experiences of their students particularly as they prepare them for adulthood and citizenship. Often these experiences are combined in the community service and internship opportunities and programs that these schools facilitate. Meier (1995) explains, "There are, in the end, only two main ways human beings learn: by observing others (directly or vicariously) and by trying things out for themselves. Novices learn from experts and from experience" (p. 181). CES schools facilitate these types of experiences often with adult learning partners outside of the classroom and school's walls. When learning occurs in the real world something happens within the student. Wood (2005) captured this explaining, "When we know something depends on our behavior solely, when it is up to us to make a difference, then we are more likely to step up to the challenge" (p. 137). And when the educational activity involves service to others, Noddings (2004) explains that these service experiences provide goods and satisfactions (happiness) that are extrinsic to the service provider and helps make them aware "that their work sustains the spirit of community and the democratic mode of association" (p. 237). Isn't this an aim of education in a democracy as ours? These Internship and service opportunities are guided by the CES principles: Learning to use one's mind well, Personalization, Demonstration of mastery, and Democracy and equity.

Maxine Greene High School (MGHS) offers students a variety of internship opportunities within and outside the school community. The internship program allows the intern to gain training and experience in an authentic job situation. Not only are real applications to academic knowledge fostered through these internships, additionally they provide students with real, practical experience in job-seeking as all internship applicants must write application letters and go through an interview process prior to receiving the internships. Communications internships range from videography and photography, sound production, and graphic design and publications. MGHS Course Catalogue describes that the graphic design and publications interns will be responsible for print and Web communication tools for MGHS to include writing and page design using related software as Adobe Creative Suite and Contribute. Interns conduct interviews and work with a team while maintaining journalistic ethics. Interns create posters, postcards and Web announcements for MGHS events and write press releases for events such as fieldtrips, guest speakers, and Exhibitions of Learning (p. 25). Greenthumbs and environmental science internships are available for students interested in plant sciences. MGHS Course Catalogue describes that these interns will:

Develop "greenhouse" or indoor plant culture skills by working with decorative and edible plants ... use high and low tech equipment including: light stands, timers, vermiculture boxes, habitat tanks, hydroponic rooters, window farms, and humidifiers. Entrepreneurial skills will come into play with the marketing and sale of heirloom vegetables and native plants in the spring. [and] ... extend their experiences into the community by assisting in the design and care of public gardens. (Maxine Green High School, 2012a, p. 26)

While interns work in their chosen fields, as much as professionals would, an expert-mentor teacher and a community professional guide them. A high level of responsibility and motivation is required for these positions, as interns contribute important skills and products to the MGHS community (Maxine Green High School, 2012c, p. 6).

Internships are available to juniors and seniors at John Dewey High School (JDHS) and they are guided through their internship coordinator. In the past, students have interned in doctor's offices, law offices, construction companies, engineering firms and many others places. Bill Steel discussed how JDHS internship program fits with their academic program. Says Steel:

It is when the kids begin to build the curriculum themselves . . . they make the decisions like, ok I'm going to go into sciences, or I'm going into medicine, or I'd like to teach. So, I'm going to do an internship and I'm going to take more math and we'll help them make a package ... this ends up helping a lot of our kids get into college and get scholarships. (B. Steel, personal communication)

Frequently community service may be integrated with JDHS' internships, as citizenship development is an important goal and graduation requirement at 
JDHS as it is one of their three graduation portfolio sections. Bill Steel explains:

Kids get different points for accomplishing different things, being engaged with civic things as being a volunteer fireman, writing letters to the editor [at the local paper], or if you are a club officer or president. It matters if you are engaged; I think citizenship is about showing up. It is when your community has a need and it is about showing up [to take care of that need]. (B. Steel, personal communication)

While Jane Adams High School (JAHS) has a sixty-hour community service graduate requirement, they also have an office for community based learning opportunities. This office was created with the assistance of the local United Way office and assists students in developing community-based learning opportunities. These learning opportunities often parallel students Junior Pathways and Senior Exhibitions projects. The intention of these projects is to develop and facilitate place-based pedagogy that seeks to help build community partnerships between students and their communities to assist in solving community problems. Here the student's local community becomes the primary resource for learning and at the same time the student's civic mindedness may be developed though the servicelearning experience. Through the assistance of the community partnership office student are better connected and grounded locally in the history, ecology, culture and of their surrounding environment. For instance, one student's Senor Exhibition might be to document to lives of women who work in the textile industry in the 1960s. This student plans to interview a number of women, collecting their stories for a radio-spot, newspaper article and a larger documentary repot. The community partnership office will assist the student in locating women who maybe living in retirement and assisted living homes in the area. In this case, the use of local people to support the student's learning would not only lead to greater comprehension of the lives of these women and the working conditions they endured, but also to understanding more about the history of their community and the people in it and at the same time serving the community in documenting the lives of the women for their families and the community.

This last working hypothesis that emerges from these schools offers students' opportunities to practice and experience real situations while still under the guidance of their teachers and advisors, this allows students the chance to succeed and fail within a learning environment. Guided by the CES principles: learning to use one's mind well, personalization, demonstration of mastery, and democracy and equity students gain a sense of confidence in their own abilities, as well as what it means to give back to their community. Through internships and service learning experiences students not only gain valuable practical knowledge and skills, but also experience the satisfaction of doing something that is real and meaningful to not only themselves but also their partners in service, as well as a deeper sense of commitment to the communities they come from.

\section{Conclusion}

This qualitative inquiry's aim was to tell the "stories" of the three selected schools and weave the commonalities that joined them not only by their affiliation with the Coalition of Essential Schools, but also by their similar rural and small school demographics. CES as an educational reform model has sustained thirty years of resiliency and yet perhaps unfamiliarity. Although demographically the schools studied in this inquiry are in many ways similar to other schools in rural areas nationwide, they also are like every school community, unique. Thus while there are limitations to the working hypotheses, and as the qualitative findings develop, there is recognition that they are contextually bound to the specific schools, teachers and their communities. And yet, they have promise. This research aims to provide rural citizens, educators and policy makers with examples, analysis and working hypotheses that can be assistive in conversations about how to best prepare their students for the challenges our twenty-first century pluralistic democracy brings. And while there are many models available, this research looks at schools specifically in rural areas. I highlighted this so that the above stakeholders might know there are identifiable characteristics similar to schools in rural areas that have working models that have had success and continue to grow in their reform efforts.

The themes addressed in this qualitative inquiry identified four prevalent working hypotheses found in each school that are foundationally connected to the Coalition of Essential Schools common principles. They are: (1) Educational justice, democracy, and citizenship, (2) The educational value of interpersonal relationships between teachers and students, (3) Pedagogical/curricular organization to enhance student engagement and learning, and (4) Pathways to adulthood via the world. It is these four working hypotheses that are seen threaded through the framework and "stories" of each school that may be useful departure points for school districts in rural areas that are ready to begin, continue or strengthen their reform conversations. 


\section{References}

Anderson, L. \& Shirley, R. (1995). High school principals and school reform: Lessons learned from a statewide study of project re: Learning. Educational Administration Quarterly, 31(3), 405-423.

Atkison P., Coffey A., \& Delmont S. (2003). Key themes in qualitative research: Continuities and change. Walnut Creek,CA: AltaMira Press.

Brown, C. (2014). Patterns of innovation. Education Digest, 79(9), 37-42.

Budge, K. (2006). Rural leaders, rural places: Problem, privilege, and possibility. Journal of Research in Rural Education, 21(13). Retrieved from http://jrre.psu.edu/articles/21-13.pdf

Charmaz, K. (2000). Grounded theory: Objectivist and constructivist methods. In N. Denzin \& Y. Lincoln (Eds.). Handbook of qualitative research (2nd ed., pp. 509 - 536). Thousand Oaks, CA: Sage Publications, Inc.

Charmaz, K. (2008). Grounded theory in the $21^{\text {st }}$ century: Applications for advancing social justice studies. In N. Denzin \& Y. Lincoln (Eds.). Strategies of qualitative inquiry (3rd ed., pp. 203 - 241).Los Angeles, CA: Sage Publications, Inc.

Chilcott, L. (Producer). \& Guggenheim, D. (Director). (2010). Waiting for superman [Motion picture]. United States: Paramount Vantage.

Coalition of Essential Schools (2012). CES common principles. Retrieved from http://www.essentialschools.org/items/4

Coladarci, T. (2007). Improving the yield of rural education research: An editor's swan song. Journal of Research in Rural Education, 22(3). Retrieved from http://jrre.psu.edu/articles/223.pdf

Darling-Hammond, L. (2010). The flat world and education: How America's commitment to equity will determine our future. New York: Teachers College Press.

Denzin, N. \& Lincoln, Y. (2000). Strategies of inquiry. In N. Denzin \& Y. Lincoln (Eds.). Handbook of qualitative research (2nd ed., pp. 366 - 376). Thousand Oaks, CA: Sage.

Dewey, J. (1897). My pedagogic creed. The School Journal, 54(3), 77-80.

Dewey, J. (1899/1907). The School and Society. Chicago: University of Chicago Press.

Dewey, J. (1916). Democracy and education: An introduction to the philosophy of education. New York: Macmillan.

Dewey, J. (1938/1997). Experience and education. New York: Free Press.
Freire, P. (1970/2000). Pedagogy of the oppressed. New York: Continuum International.

Freire, P. (1998). Pedagogy of freedom: Ethics, democracy, and civic courage. New York: Rowman \& Littlefield.

Freire, P. (2006). Teachers as cultural workers: Letters to those who dare teach (Expanded ed.). Boulder, CO: Westview Press.

Jane Adams High School. (2012a). Jane Adams High School: Handbook.

Jane Adams High School. (2012b). Jane Adams High School: Program of Study.

Jane Adams High School. (2012c). Jane Adams High School's mission statement and guiding principles.

John Dewey High School. (2012a). John Dewey High School: Senior Year Handbook.

John Dewey High School. (2012b). John Dewey High School: Small schools big futures.

Johnson, J., Showalter, D., Klein, R., \& Lester, C. (2014). Why rural matters 2013-14: The condition of rural education in the 50 states. Washington, DC: Rural School and Community Trust.

Kannapel, P. (2000). Standards-based reform and rural school improvement: Finding the middle ground. Journal of Research in Rural Education, 16(3), 202-208.

Kannapel, P. \& DeYoung, A. (1999). The rural school problem in 1999, Journal of Research in Rural Education, 15(2), 67-79.

Lawrence, D. H. (1994). The complete poems of D. H. Lawrence. New York: Wordsworth Editions Ltd.

Lincoln, Y., \& Guba, E. (1985). Naturalistic inquiry. Newbury Park, CA: Sage Publications.

Maxine Green High School. (2012a). Maxine Green High School: Course catalogue.

Maxine Green High School. (2012b). Maxine Green High School: Our mission/vision.

Maxine Green High School. (2012c). Maxine Green High School: Program of Study.

Meier, D. (1995). The power of their ideas: Lessons for America from a small school in Harlem Boston: Beacon Press.

National Center for Education Statistics. (2012). Rural education in America. Retrieved from http://nces.ed.gov/surveys/ruraled/definitions.as $\mathrm{p}$

Noddings, N. (1984). Caring: A feminine approach to ethics \& moral education. Berkeley: University of California Press. 
Noddings, N. (1992). The challenge to care in schools: An alternative approach to education. New York: Teachers College Press.

Noddings, N. (2004). Happiness and education. Boston: Cambridge University Press.

Partnership for 21st Century Skills. (2014). Framework for 21 st century learning. Retrieved from http://www.p21.org/our-work/p21framework

Patton, M. (2002). Qualitative research and evaluation methods. Thousand Oaks, CA: Sage.

Powell, D., Higgins, H., Aran, R., \& Freed, A. (2009). Impact of No Child Left Behind on curriculum and instruction in rural schools. The Rural Educator, 31(1), 19-28.

Sackler, M. (Producer). \& Sackler, M. (Director). (2010). The Lottery [Motion picture]. United States: Great Curve Films.

Schafft, K. (2010). Economics, community, and rural education: Rethinking the nature of accountability in the twenty-first century. In Schafft, K. \& Jackson, A. (Eds). Rural education for the twenty-first century: Identity, place, and community in a globalizing world. University Park, PA: Pennsylvania State University Press.

Seidman, I. (1998). Interviewing as qualitative research: A guide for researchers in education and the social sciences. New York: Teachers College Press.

Sizer, T. (1973). Places for learning, places for joy: Speculations on American school reform. Cambridge, MA: Harvard University Press.
Sizer, T. (1983), Essential schools: A first look. NASSP Bulletin. 67(465), 33-38.

Sizer, T. (1984). Horace's compromise: The dilemma of the American high school. Boston: Houghton Mifflin Company.

Sizer, T. (1992). Horace's school: Redesigning the American high school. Boston: Houghton Mifflin Company.

Sizer, T. (1996). Horace's hope: What works for the American high school. Boston: Houghton Mifflin Company.

Sizer, T. (Ed.) (2004). Breaking ranks II: Strategies for leading high school reform. Providence, RI: The Education Alliance.

Strauss, A. \& Corbin, J. (1990). Basics of qualitative research: Grounded theory procedures and techniques. Newbury Park, CA: Sage.

Toch, T. (2010). The Sizer Legacy, Phi Delta Kappa, 91(5), 74-5.

Trilling, B. \& Fadel, C. (2009). 21st century skills: Learning for life in our times. San Francisco: Jossey-Bass.

Tyack, D. (1972). The tribe and the common school: Community control in rural education. American Quarterly, 24(1), 3-19.

Wagner, T. (2008). Global achievement gap: Why even our best schools don't teach the new survival skills our children need - and what we can do about it. New York: Basic Books.

Wood, G. (2005). Time to learn: How to create high schools that serve all students (2nd ed.). Portsmouth, NH: Heinemann.

\begin{abstract}
About the Author:
Dr. Jim La Prad is an Associate Professor in the Educational \& Interdisciplinary Studies and Educational Leadership Department at Western Illinois University.
\end{abstract}


